\title{
Seasonality analysis of water losses in a selected collective water supply system
}

\author{
Jakub Żywiec ${ }^{1, *}$, and Barbara Tchórzewska-Cieślak ${ }^{1}$ \\ ${ }^{1}$ Rzeszow University of Technology, Faculty of Civil and Environmental Engineering and Architecture, \\ Department of Water Supply and Sewage Systems, al. Powstańców Warszawy 12, 35-959 Rzeszów, \\ Poland
}

\begin{abstract}
The aim of the study is to analyse the seasonality of water losses from a collective water-supply system (CWSS) on the example of a provincial city located in south eastern Poland. The analysis was based on exploitation data obtained from the water-supply company for the period 2012-2016. For the analysis of seasonality a method based on average homogeneous sub-periods was used, with a relative seasonality index and the absolute levels of seasonal fluctuations being determined. Water losses from the analysed CWSS are also characterised using unit water-volume indicators within the water supply network. Over the research period, the volume of water produced and sold was found to decline, even as the number of inhabitants using the network increased. On the other hand, there is a growing demand for water used for own purposes by company, as related directly to their development. Water losses and values determined for the water-loss volume indicator both show a downward trend for the analysed CWSS. It is further observed that, in January, March and May, the loss of water is above average, while the volume of water lost in the other months is below average.
\end{abstract}

\section{Introduction}

Ongoing climate change requires the management of natural resources to be both rational and economical. Particular attention should be paid to resources of fresh water, because of their declining availability as a consequence of urbanisation, industrial and agricultural development and growth in the human population. According to a UN Resolution of 28 June 2010, access to drinking water is nothing less than a fundamental human right. Poland has some of the most limited water resources of any European country [1], making the saving of water at the levels of both the consumer and the water-supply company a matter of considerable importance. Analyses of losses from collective water-supply systems (CWSS) have featured in many scientific publications [2-9], but the matter remains a current one, worthy of further research, and the limitation of water losses need to be a priority for operators of water-supply networks.

Loss of water is a problem for every water-supply system, reflecting the difference between the volumes of water produced and sold and the amount of water used for

* Corresponding author: j.zywiec@prz.edu.pl 
companies' own purposes. Such losses of water can be classed as [5]: apparent losses (resulting from inaccuracies of measurement devices and measurement inconsistencies, but also the theft of water) or real losses (as the sum of water lost in reservoirs, water connections and via leaks, due to failures of mains and distribution-network pipelines). $80-100 \%$ of total losses are reflected by real losses [4], in particular those relating to pipeline failures. The exploitation of a water-supply network in terms of water losses is aimed to limit them, to minimise their potential negative effects on unit water costs, company profitability and the excessive use of water resources. Water supply companies have therefore to apply a proper renovation and repair strategy, ensuring that the costs of removing sources of leakage do not exceed the monetary value of the water wasted. Every system has its level of unavoidable water loss, the elimination of which would be uneconomical. These relate directly to the length of the network, the number and length of water connections, and the pressure in the analysed system. The current trend is to determine an optimal level of losses, a process that entails complicated economic analysis including costs: of producing and distributing water, of active monitoring of the network, and of removing leaks, as well as the resource and environmental costs of water being wasted [5, 6, 10-12].

Like many other phenomena, the loss of water is characterised by a certain unevenness and variability over time. Knowledge of these relationships is a valuable hint for operators, allowing amounts of water lost to be linked with other operating parameters of the water-supply network during the year, such as pressure, the failure rate of pipelines, or external factors like air temperature [13]. This information can be used in planning the schedule for renovation and repairs, in a manner that ensures priority renewal for the pipelines failing most often, with a view to preventing breakdown and limiting amounts of water lost from the supply network.

The main purpose of this paper is to analyse seasonal fluctuations in losses of water and their characteristics, by water-volume indicators within the water supply network in the selected CWSS.

\section{Research methodology}

The occurrence of seasonal fluctuations was examined using a method based on average homogeneous sub-periods $[14,15]$. This assumes seasonality indicators $S_{\mathrm{i}}$ (relative index) being determined in line with formula (1):

$$
\begin{gathered}
S_{i}=\frac{\bar{y}_{i} \cdot d}{\sum_{i=1}^{d} \bar{y}_{i}} \cdot 100 \% \\
\bar{y}_{i}=\frac{\sum_{i=1}^{d} k_{i}}{d}
\end{gathered}
$$

where:

$S_{\mathrm{i}}$ - the value of the seasonal fluctuations index for the i-th sub-period,

$\bar{y}_{i}$ - the arithmetic mean for the size of the phenomenon studied in homogeneous sub-periods (months),

$d$ - the number of the sub-period (12 months),

$k_{\mathrm{i}}$ - the size of the phenomenon studied in the i-th sub-period.

The correctness of calculations is determined by reference to the sum of $S_{\mathrm{i}}$ indicators, which should equal 1200 , for the monthly seasonality analysis. 


$$
\sum_{i=1}^{12} S_{i}=1200
$$

Another measure describing seasonal fluctuations is the absolute seasonality index (absolute level of seasonal fluctuations). This is expressed in the same units as the studied phenomenon. This index is determined for each analysed sub-period in line with formula (4):

$$
\begin{aligned}
\pm g_{i} & =S_{i} \cdot \bar{y}-\bar{y} \\
\bar{y} & =\frac{\sum_{i=1}^{12} \overline{y_{l}}}{12}
\end{aligned}
$$

where:

$g_{\mathrm{i}}$ - the absolute level of seasonal fluctuations,

$\bar{y}-$ the arithmetic mean for the magnitude of the phenomenon studied.

The sum of the absolute seasonal fluctuation levels $g_{\mathrm{i}}$ should be equal to 0 where analysis is performed properly.

$$
\sum_{i=1}^{12} g_{i}=0
$$

In the study, values of unit indicators of water volumes in the water-supply network were presented, as basic parameters allowing the sizes of water losses and the hydraulic load of the network to be determined. We can distinguish among these $[4,6,11,15]$ :

- the water-produced volume indicator:

$$
q_{w t l}=\frac{V_{w t l} \cdot 1000}{L M \cdot 365}, \frac{d m^{3}}{M \cdot d}
$$

where:

$V_{\text {wtl }}$ - the volume of water produced, $\mathrm{m}^{3}$,

LM - the number of inhabitants using the network.

- the water-sold volume indicator:

$$
q_{s p}=\frac{V_{s p} \cdot 1000}{L M \cdot 365}, \frac{d m^{3}}{M \cdot d}
$$

where:

$V_{\mathrm{sp}}$ - the volume of water sold, $\mathrm{m}^{3}$.

- the water used for own purposes volume indicator:

$$
q_{c w}=\frac{V_{c w} \cdot 1000}{L M \cdot 365}, \frac{d m^{3}}{M \cdot d}
$$

where:

$V_{\mathrm{cw}}$ - the volume of water used by the company for its own purposes, $\mathrm{m}^{3}$.

- the water-loss volume indicator:

$$
q_{s t r}=\frac{V_{s t r} \cdot 1000}{L M \cdot 365}, \frac{d m^{3}}{M \cdot d}
$$

where:

$V_{\text {str }}$ - the volume of water losses, $\mathrm{m}^{3}$. 


$$
V_{s t r}=V_{w t l}-V_{s p}-V_{c w}, m^{3}
$$

- the non-profit water volume indicator:

$$
q_{n d}=\frac{\left(V_{w t l}-V_{s p}\right) \cdot 1000}{L M \cdot 365}, \frac{d m^{3}}{M \cdot d}
$$

- the hydraulic load indicator for the water-supply network:

$$
q_{o}=\frac{V_{w t l}}{L_{M+R} \cdot 365}, \frac{\mathrm{m}^{3}}{\mathrm{~km} \cdot \mathrm{d}}
$$

where:

$L_{\mathrm{M}+\mathrm{R}}$ - the summed length of the mains and distribution network, $\mathrm{km}$.

- the indicator of water-loss volume in relation to the length of the network:

$$
q_{s t r L}=\frac{V_{s t r}}{L \cdot 365}, \frac{\mathrm{m}^{3}}{\mathrm{~km} \cdot \mathrm{d}}
$$

where:

$L$ - the total length of the network, $\mathrm{km}$.

\section{Research object}

The analysis was performed for the collective water supply system (CWSS) of a city located in south-eastern Poland, with an area of $120.4 \mathrm{~km}^{2}$. About 200,000 inhabitants use the watersupply network, and the average demand for water is of $36,000 \mathrm{~m}^{3} / \mathrm{d}$. The total length of the network is $1006.6 \mathrm{~km}$ (in 2016), of which $54.9 \mathrm{~km}$ is the mains network, $585.5 \mathrm{~km}$ the distribution network, and $365.2 \mathrm{~km}$ of water connections. The research was based on exploitation data provided by the water-supply company in the period 2012-2016, including: volumes of water produced, water sold and water used by the company for its own

\begin{tabular}{|c|c|c|c|c|c|c|c|}
\hline \multirow[b]{2}{*}{ Year } & \multirow[b]{2}{*}{$V_{\mathrm{wt}}, \mathbf{m}^{3}$} & \multirow[b]{2}{*}{$V_{\mathrm{sp}}, \mathrm{m}^{3}$} & \multirow[b]{2}{*}{$V_{\mathrm{cw}}, \mathbf{m}^{3}$} & \multirow[b]{2}{*}{$\mathbf{L M}$} & \multicolumn{2}{|c|}{ Length of network: } & \multirow{2}{*}{$\begin{array}{c}\text { Lenght of } \\
\text { water } \\
\text { connection, } \\
\text { km }\end{array}$} \\
\hline & & & & & $\begin{array}{c}\text { main, } \\
\text { km }\end{array}$ & $\begin{array}{c}\text { distribution, } \\
\mathbf{k m}\end{array}$ & \\
\hline 2012 & 13123532 & 9719587 & 1589406 & 167155 & 49.8 & 520.5 & 323.8 \\
\hline 2013 & 12995329 & 9750269 & 1639039 & 171827 & 49.8 & 524.8 & 324.0 \\
\hline 2014 & 13079211 & 9861071 & 1734834 & 180839 & 49.8 & 529.0 & 324.0 \\
\hline 2015 & 13819560 & 10084749 & 1867238 & 181709 & 49.8 & 540.4 & 324.3 \\
\hline 2016 & 13160958 & 10113934 & 1895640 & 183310 & 54.9 & 586.5 & 365.2 \\
\hline
\end{tabular}
purposes present in annual and monthly statements, numbers of inhabitants using the watersupply network and length of the network.

Table 1. Operating data in the period 2012-2016

\section{Results}

For the seasonal analysis of water losses, the month was selected as a homogeneous subperiod in each analysed year (2012-2016). The sizes of water losses in the different months are as shown in Fig. 1. 


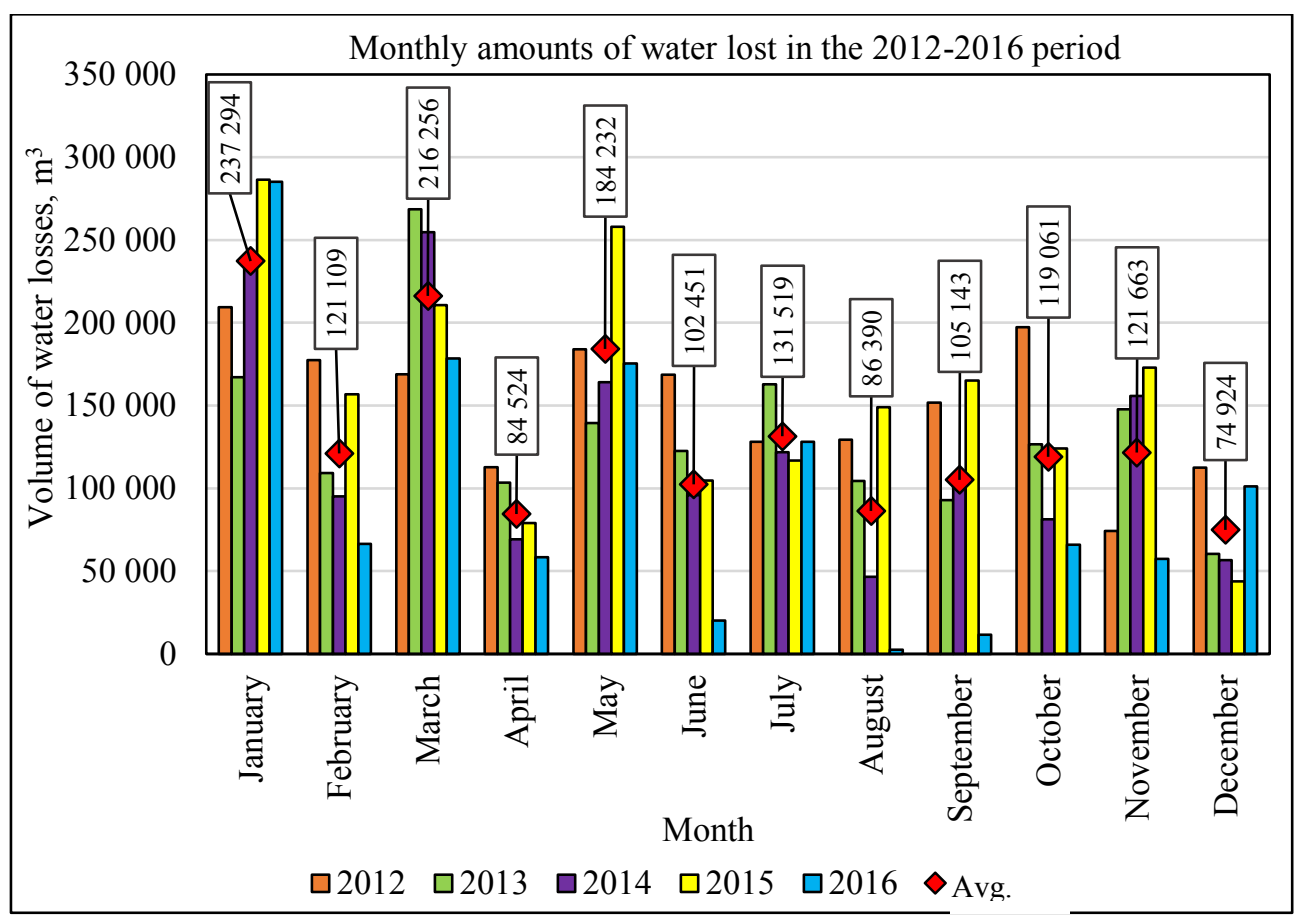

Fig. 1. The volumes of water lost in particular months (sub-periods).

Table 2 shows the calculation of values for the relative seasonal fluctuation index $S_{\mathrm{i}}$ and absolute seasonal fluctuation levels $g_{i}$. For monthly sub-periods of seasonal fluctuations, the sum of values of the relative seasonality index $S_{\mathrm{i}}$ should be $\Sigma S_{\mathrm{i}}=1200$, while the sum of absolute seasonal fluctuations levels $\Sigma g_{\mathrm{i}}=0$. This proves the correctness of calculations.

Table 2. Relative and absolute seasonal fluctuations in water losses over the 2012-2016 period.

\begin{tabular}{|c|c|c|c|c|c|c|c|c|c|}
\hline \multirow{2}{*}{ Month } & \multicolumn{5}{|c|}{ Year } & \multirow[b]{2}{*}{ Sum } & \multirow[b]{2}{*}{$\overline{\mathbf{y}}_{\mathbf{i}}$} & \multirow{2}{*}{$S_{\mathrm{i}}, \%$} & \multirow[b]{2}{*}{$g_{\mathrm{i}}$} \\
\hline & 2012 & 2013 & 2014 & 2015 & 2016 & & & & \\
\hline I & 209332 & 167177 & 238323 & 286351 & 285287 & 1186470 & 237294 & 179.7 & 105247 \\
\hline II & 177554 & 109349 & 95228 & 156853 & 66561 & 605545 & 121109 & 91.7 & -10938 \\
\hline III & 168981 & 268560 & 254619 & 210668 & 178452 & 1081280 & 216256 & 163.8 & 84209 \\
\hline IV & 112707 & 103442 & 69132 & 78991 & 58346 & 422618 & 84524 & 64.0 & -47523 \\
\hline $\mathbf{V}$ & 183959 & 139456 & 164182 & 258118 & 175444 & 921159 & 184232 & 139.5 & 52185 \\
\hline VI & 168703 & 122662 & 95844 & 104854 & 20191 & 512254 & 102451 & 77.6 & -29596 \\
\hline VII & 128227 & 162768 & 121792 & 116760 & 128049 & 657596 & 131519 & 99.6 & -528 \\
\hline VIII & 129299 & 104517 & 46554 & 149018 & 2560 & 431948 & 86390 & 65.4 & -45657 \\
\hline IX & 151811 & 93019 & 103931 & 165237 & 11716 & 525714 & 105143 & 79.6 & -26904 \\
\hline $\mathbf{X}$ & 197239 & 126645 & 81290 & 124031 & 66100 & 595305 & 119061 & 90.2 & -12986 \\
\hline XI & 74173 & 147878 & 155771 & 172958 & 57534 & 608314 & 121663 & 92.1 & -10384 \\
\hline XII & 112554 & 60548 & 56640 & 43734 & 101144 & 374620 & 74924 & 56.7 & -57123 \\
\hline & & & & & & & Sum: & 1200 & 0 \\
\hline
\end{tabular}

Fluctuations in values for the seasonality index $S_{\mathrm{i}}$ show differences in volumes of water lost in each sub-period as compared with the average monthly loss in the analysed period $\bar{y}=132,047 \mathrm{~m}^{3}\left(S_{\mathrm{i}}=100 \%\right)$. Fig. 2 . shows the direct influence of seasonal fluctuations $\left(S_{\mathrm{i}}-100 \%\right)$ and absolute fluctuation levels $\left(g_{\mathrm{i}}\right)$ on the sizes of water losses characterising each month. 


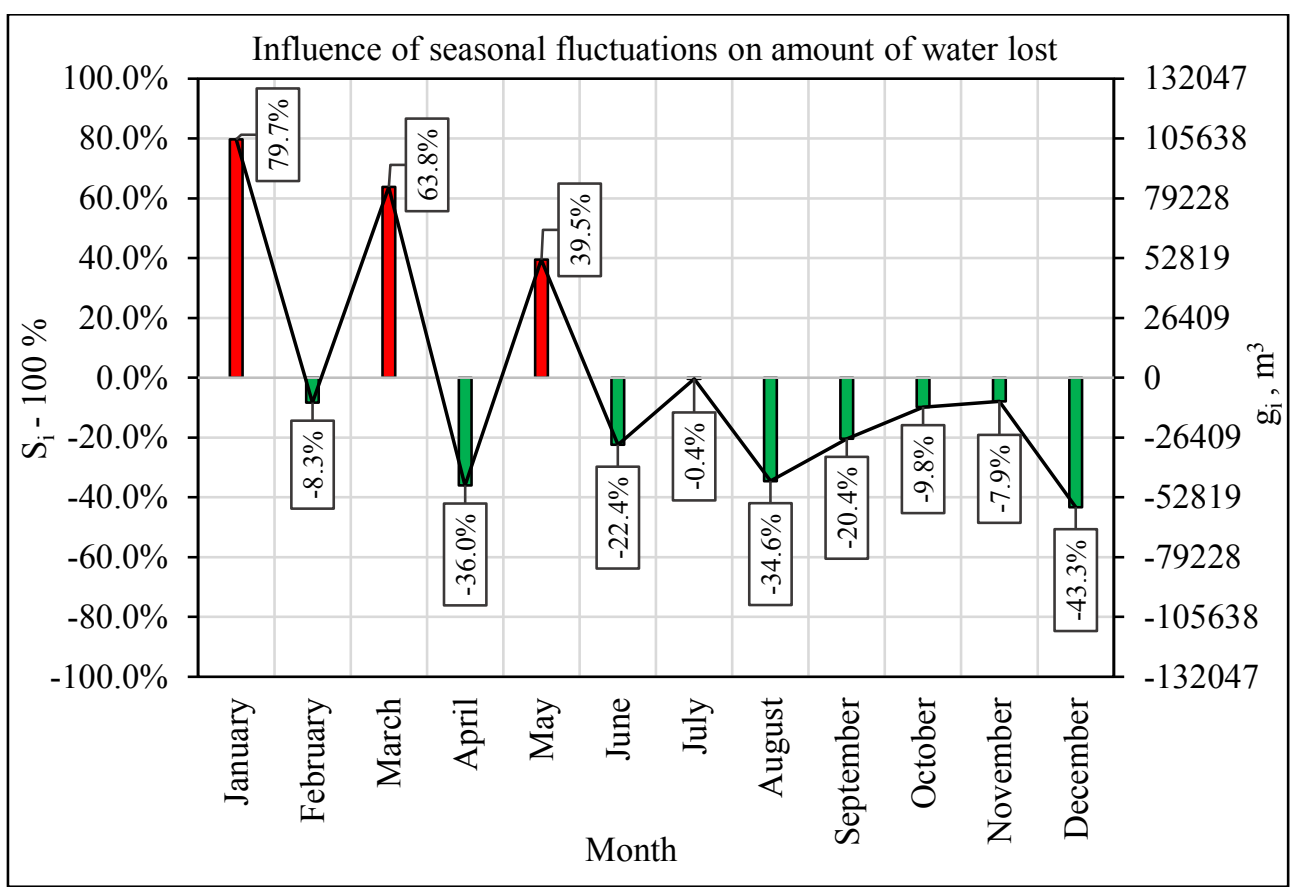

Fig. 2. The influence of relative seasonal fluctuations and absolute fluctuation levels on amounts of water lost.

The absolute levels of seasonal fluctuations $g_{\text {i }}$ quantify differences in amounts of water lost in comparison with the average $\bar{y}\left(g_{\mathrm{i}}=0\right)$. The index $g_{\mathrm{i}}$ adopts a unit for the analysed phenomena, its sign revealing whether in a given sub-period the amount was above or below the average value in the examined period.

The highest seasonality impact on the amount of water lost is observed in January, for which the relative seasonality index $S_{\mathrm{i}}=179.7 \%$, as corresponding with an absolute level of seasonal fluctuations $g_{i}$ equal to $105,247 \mathrm{~m}^{3}$. This means that the size of the water loss in this month is of $79.9 \%$, and is $105247 \mathrm{~m}^{3}$ greater than the average value for the analysed period, $\bar{y}=132,047 \mathrm{~m}^{3}(100 \%)$. Increased losses of water in relation to the average value were also observed in March and May. In other months: February, April, June, July, August, September, October, November and December, the amounts of water lost are lower than the average value for the analysed period. The highest value of reduction in size of the loss of water in comparison with the average value, was observed in December (at $43.3 \%$ ). This

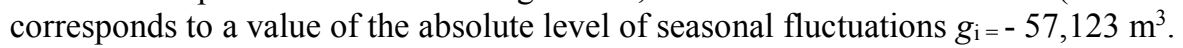

In the first half of the year, an increase in values for the seasonality index is to be observed (meaning that the amount of water lost is above average). One of the main causes of water loss is leakage associated with failure of the water-supply network. Losses increase in size as a result of greater numbers of failures, during the winter-spring period especially. This is followed by a periodic decrease in the sizes of water losses due to ongoing repair work being carried out on failing pipelines. The second half of the year is then characterised by reduced (below-average) amounts of water lost (with the seasonality index $S_{\mathrm{i}}<100 \%$ and absolute levels of seasonal fluctuations being negative). Repair and replacement work along failing pipelines improves the network's technical condition, reducing both numbers of failures and amounts of water lost in summer and autumn. Knowledge regarding the seasonality of this phenomenon may be helpful as renovation and repair plans will be prepared. A proper renewal strategy will help reduce sizes of water losses, preventing failures of pipes and uncontrolled leakage. 
Table 3 presents calculations of amounts of water lost, water volume indicators in the water-supply network and hydraulic load indicators. Fig. 3 presents changes in values for the selected unit indicators over the analysed period.

Table 3. Unit water-volume indicators and the hydraulic load indicator on the network.

\begin{tabular}{|c|c|c|c|c|c|c|c|c|}
\hline Year & $V_{\text {str }}, \mathbf{m}^{3}$ & $\begin{array}{r}q_{\mathrm{wtl}} \\
d^{3} m^{3}\end{array}$ & $\begin{array}{c}q_{\mathrm{sp}} \\
d m^{3}\end{array}$ & $\begin{array}{c}q_{\mathrm{cw}} \\
\mathrm{dm}^{3}\end{array}$ & $\begin{array}{r}q_{\text {str }} \\
d^{3} m^{3}\end{array}$ & $\begin{array}{c}q_{\mathrm{nd}} \\
\boldsymbol{d m}^{3}\end{array}$ & $\begin{array}{r}q_{0} \\
m^{3}\end{array}$ & $\begin{array}{c}q_{\text {strL }} \\
m^{3}\end{array}$ \\
\hline & & $\overline{M \cdot d}$ & $\overline{M \cdot d}$ & $\overline{M \cdot d}$ & $\overline{M \cdot d}$ & $\overline{M \cdot d}$ & $\overline{\mathrm{km} \cdot \mathrm{d}}$ & $\overline{\mathrm{km} \cdot \mathrm{d}}$ \\
\hline 2012 & 1814539 & 215.1 & 159.3 & 26.1 & 29.7 & 55.8 & 63.0 & 5.6 \\
\hline 2013 & 1606021 & 207.2 & 155.5 & 26.1 & 25.6 & 51.7 & 62.0 & 4.9 \\
\hline 2014 & 1483306 & 198.2 & 149.4 & 26.3 & 22.5 & 48.8 & 61.9 & 4.5 \\
\hline 2015 & 1867573 & 208.4 & 152.1 & 28.2 & 28.2 & 56.3 & 64.2 & 5.6 \\
\hline 2016 & 1151384 & 196.7 & 151.2 & 28.3 & 17.2 & 45.5 & 56.2 & 3.1 \\
\hline
\end{tabular}

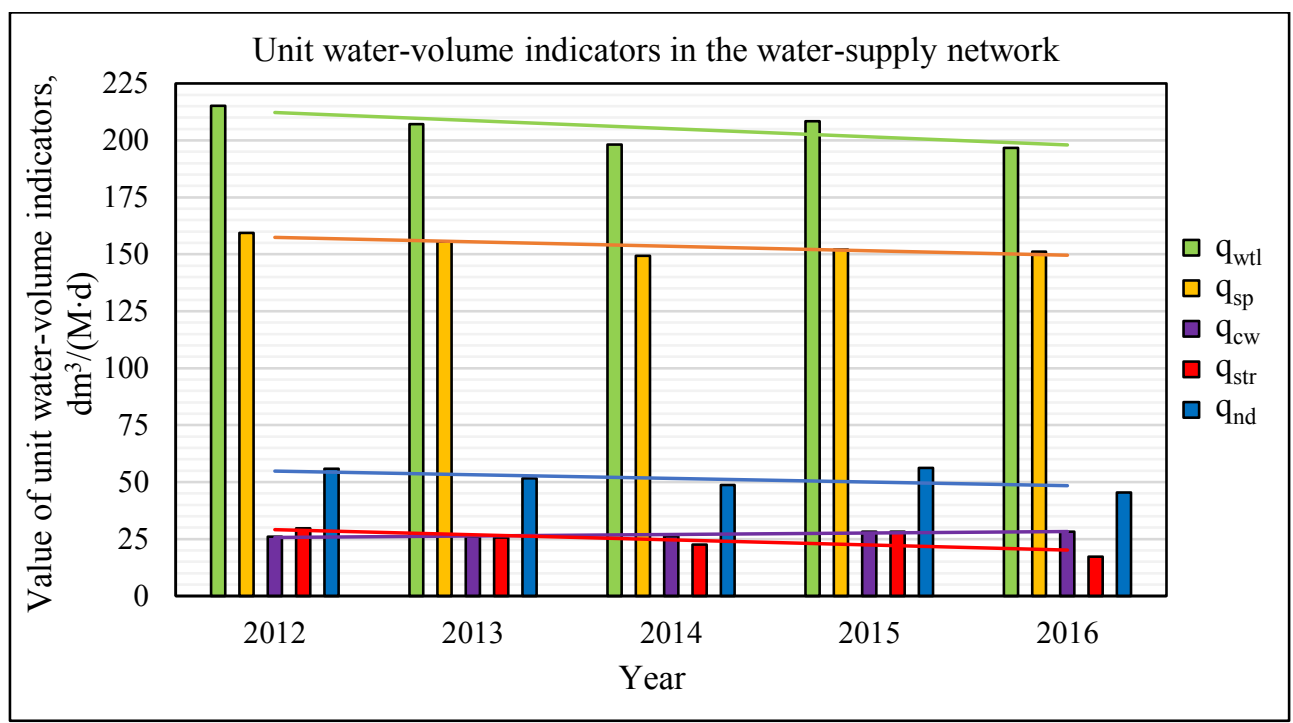

Fig. 3. Unit water-volume indicators in the water-supply network.

The analysis performed showed a decrease (defined by the trend line) for the water-produced volume indicator $q_{\mathrm{wtl}}$ and the water-sold volume indicator $q_{\mathrm{sp}}$ with observable growing number of inhabitants using the water supply. This phenomenon inscribe in global trend of environment-friendly lifestyle, which include water saving among the other things. Values noted for both the water-loss volume indicator $q_{\text {str }}$ and the non-profit water-volume indicator $q_{\text {nd }}$ were in decline over the examined period, due to achieved reductions in amounts lost that reflect an improved technical condition of the network thanks to the repair or replacement of failing pipelines. The indicator concerning water used for companies' own purposes $-q_{\mathrm{cw}}-$ is characterised by a slight increase, which relates directly to the development of the water-supply network in the period under analysis. With the reduction in the hydraulic load on the network, as described by the $q_{\mathrm{o}}$ indicator, values for the indicator of volume of water lost in relation to the length of the network have also displayed a downward trend.

\section{Conclusion}

The growing population, progressive urbanization, development of industry and agriculture, and climate change all threaten the size of water resources, making it important for the latter 
to be used properly and rationally. Water should be saved at the consumption, production and distribution stages. However, as water losses from a water-supply network should be minimised to a level that is optimal, the phenomenon requires deep, multifaceted analysis.

Based on the seasonality studies, it was observed that the year may be divided into two periods. The first of these includes winter and spring months and is characterised by above-average losses of water $\left(\bar{y}=132,047 \mathrm{~m}^{3}\right)$. In contrast, in the summer and autumn months water losses are of below-average size. The highest value for the seasonality index was the $S_{\mathrm{i}}=179.7 \%$ recorded in January, while the lowest was the $S_{\mathrm{i}}=56.7 \%$ noted for December. The $g_{i}$ index quantifies the difference in the loss of water as compared with the average figure. The lowest value for $g_{i}\left(\right.$ of $\left.-57,123 \mathrm{~m}^{3}\right)$ was obtained for December, while the highest was $g_{i}=+105247 \mathrm{~m}^{3}$, noted for January. The information obtained may be used by the operator of the analysed water-supply network for planning the schedule of pipeline repairs. Also noteworthy is the simplicity and universality of the methodology used, which allows for use it in characterising other phenomena in a CWSS or other municipal systems.

Analysis of water-volume indicators in the water-supply network reveals a decrease in production volume $\left(q_{\mathrm{wt}}\right)$, water consumption $\left(q_{\mathrm{sp}}\right)$ and water losses $\left(q_{\mathrm{str}}\right)$. As the water-supply network developed, there was an increase in the value of the water use for own purposes volume indicator $\left(q_{\mathrm{cw}}\right)$. Declining trend in turn describes the change in values for the network hydraulic load indicator $\left(q_{\mathrm{o}}\right)$, and the value of water-loss volume in relation to the length of the network indicator $\left(q_{\mathrm{strL}}\right)$.

\section{References}

1. M. Gutry-Korycka, A. Sadurski, Z. W. Kundzewicz, J. Pociask-Karteczka, L. Skrzypczyk, Nauka 1, 77-98 (2014)

2. T. AL-Washali, S. Sharma, M. Kennedy, Water Resour. Manag. 30, 14, 4985-5001 (2016)

3. B. B. Azevedo, T. A. Saurin, Water Resour. Manag. 32, 9, 2919-2936 (2018)

4. H. Hotloś, Ilościowa ocena wplywu wybranych czynników na parametry $i$ koszty eksploatacji sieci wodociagowych (Monografia 49, Oficyna Wydawnicza Politechniki Wrocławskiej, Wrocław, 2007)

5. E. Ociepa, M. Mrowiec, I. Deska, Proceedings of ECOpole 10, 1, 247-255 (2016)

6. K. Pietrucha-Urbanik, Advances in Intelligent Systems and Computing 470, 355-362 (2016)

7. K. Pietrucha-Urbanik, A. Studziński, Gaz, Woda i Technika Sanitarna 10, 452-454 (2012)

8. A. Studziński, K. Pietrucha-Urbanik, A. Mędrala, JCEEA 4, 193-201 (2014)

9. E. Renaud, J. Pillot, C. Aubrun, E. Bréjoux, B. Augeard, Water Sci. Tech-W Sup. 18, 1, 251-258 (2018)

10. M. Kwietniewski, J. Rak, Niezawodność infrastruktury wodociagowej i kanalizacyjnej w Polsce (Komitet Inżynierii Lądowej i Wodnej PAN, Warszawa, 2010)

11. D. Szpak, B. Tchórzewska-Cieślak, Advances in Intelligent Systems and Computing 470, 479-489 (2016)

12. J. S. Rogers, Y. Kleiner, B. J. Adams, Water Resour. Res. 34, 8, 2039-2051 (1998)

13. H. Hotloś, Ochr. Sr. 2, 57-62 (2013)

14. M. Sobczyk, Statystyka (Wydawnictwo Naukowe PWN, Warszawa, 2002)

15. I. Piegdoń, B. Tchórzewska-Cieślak, E3S Web Conferences 44, 00140 (2018) 